Hrvoje Šapina ${ }^{1}$

UDK 657.632-051(497.6)

Sabina Ibrahimagić ${ }^{2}$

Review

Pregledni rad

\title{
CAUSES OF AUDITOR MISTAKES IN PUBLISHED AUDIT REPORTS IN BOSNIA AND HERZEGOVINA
}

\begin{abstract}
The authors carried out research in which they identified errors in published audit reports carried out by some independent auditors from Bosnia and Herzegovina. They also carried out the analysis on causes for the identified errors. Through the analysis of the collected audit reports it has been established the existence of numerous deviations comparing to the requirements of the International Standards on Auditing (ISA) 700 and 701, with aspect of the formal contents of the reports as well as the essence of the reports. The research established that the causes of the identified errors are: inadequate legislature in Bosnia and Herzegovina, inadequate continuous education of the auditors, insufficiently developed auditing practice, absence or inadequate internal control of quality in most audit firms, and absence of public supervision on the state level. The recently passed law which refers to accounting and auditing opens some more space for certain improvements, especially through establishing the Audit Chamber and the Public Supervision Board.
\end{abstract}

Key words: International auditing standards, audit reports, errors of auditor.

\section{INTRODUCTION}

In auditing, there is always a risk that an auditor will unintentionally express a positive opinion on financial reports which contain considerable erroneous information. Provided that an auditor, with no exceptions stuck to the procedures regulated by the International auditing standards, he cannot be considered responsible for the unintentionally expressed the opinion which is apparently erroneous. The law on accounting and auditing of Federation of Bosnia and Herzegovina regulates application of International Standards on Auditing (ISA). These standards strictly regulate the content and the formal frame of audit reports. Consequently, the auditor which stipulates in his report that his auditing was conducted according to the ISA, is obliged to apply the legal content and formal frame in the report. By all the means of communication we have a chance to see various types and forms of audit reports. That gives us a chance to notice that those reports express reference to various audit standards, the content frames of the reports are different in respect to their scope and structure. These deviations confuse their users and consequently they often have no idea what the legal and proper audit reports should look like. In accordance to that, the research goals are defined:

Are the published audit reports in accordance with ISA, and are there any discrepancies? What are the causes of deviations found in published audit reports comparing to ISA,, are they the consequential result of the subjective weaknesses of the auditors or there are some other causes which originate from the environment? Is it possible that the deviations found in published audit reports because certain consequences related to the auditor, the users of audit reports, or the audit profession itself? The initial goal of the research was to classify

\footnotetext{
${ }^{1}$ Docent at the department of Accounting and auditing, School of economics and businesses in Sarajevo, Trg oslobođenja - Alija Izetbegović br.1, e-mail: hrvoje.sapina@efsa.unsa.ba

${ }^{2}$ Senior assistent at the department of Accounting and auditing, School of economics and businesses in Sarajevo, Trg oslobođenja - Alija Izetbegović br. 1, e-mail: sabina.ibrahimagic@efsa.unsa.ba
} 
deviations that are recognized in the audit reports, comparing to the audit reports regulated by ISA,. The explanation goals of the research are as follows:

$\square$ To analyze if the legislature in B\&H could be the cause of deviations in audit reports, comparing to ISA,.

$\square$ Examine if the auditors in $\mathrm{B} \& \mathrm{H}$ get appropriate education prior to the promotion to professional auditors, if they get appropriate continuous education, and if the educational anomalies could be the cause of the subjective weaknesses of the auditors, recognized through their erroneous audit reports.

$\square$ Compare the number of the conducted audits to the total number of companies in $\mathrm{B} \& \mathrm{H}$, and analyze if the auditors in $\mathrm{B} \& \mathrm{H}$ have the opportunity to get enough appropriate practice.

$\square$ Analyze quality control of audit business and public supervision over the audit activities in Bosnia and Herzegovina and determine if inadequate quality control and insufficiency of public supervision could be causes for errors in audit reports in Bosnia and Herzegovina comparing to ISA,.

The research started from the assumption that the main causes for deviations found in published audit reports comparing to ISA, are: inadequate legislature related to auditing business, inadequate education of auditors, inactivity of the field experts associations, absence of public supervision over auditors as well as absence of the auditing business quality control.

The multilevel empirical research was conducted by means of:

$\square$ Analysis of audit reports of commercial auditors, published in press and e-media.

$\square$ Gathering and analysis the data published in audit reports in Federation of B\&H.

$\square$ Analysis of the structure of education for certified auditors, published on the field experts associations official web pages.

$\square$ Analysis of continuous education agenda structure, published by officials in charge of continuous education.

\section{CLASSIFICATION OF TYPES OF COMMERCIAL AUDITOR AUDIT REPORT DEVIATIONS}

The law on accounting and auditing of Federation of Bosnia and Herzegovina assumes application of ISA,. Those standards clearly explain what the formal frame and the content should look like. Consequently, the auditor who stipulates in his report that the auditing was conducted in accordance to ISA, is legally obliged to apply the ISA, regulated formal frame as well as the content. Despite of that obligation we recognize various different formal frames and text bodies of audit reports through media and other means of public communication. Analyzing the commercial auditor audit reports published by printing media ("Dnevni avaz", "Oslobođenje", "San" - all from Sarajevo) and e-media in 2009, certain deviations in audit reports compared to ISA, are noticed. It has been gathered and analyzed 48 samples of auditor positions which were analyzed from the point of view concerning their accordance with ISA, 700 and ISA, 701.

\subsection{ERRORS OF FORMAL NATURE}

Analyzing the gathered audit reports it was found that there is a number of deviations relating to ISA, 700 and 701 bearing the nature of formal frame and the content. Those deviations are related as follows:

a) Incompletely or incorrectly defined the subject of the auditing: In the initial part of the report it is not clearly listed the complete set of the financial statements that was the 
subject of the auditing. The most frequently, auditors fail to stipulate "Notes to the Financial Statements” as a component of a legally regulated set of a financial statement.

b) Incompletely or irregularly defined the responsibility of the Bureau for financial reports: In the chapter Management's Responsibility for the Financial Statements, in accordance with ISA 700, an auditor is supposed to use the expression: "Management is responsible for the preparation and fair presentation of these financial statements in accordance with International Financial Reporting Standards, and for such internal control as management determines is necessary to enable the preparation of financial statements that are free from material misstatement, whether due to fraud or error."

On the contrary, the analysis proved that auditors do not use the full section of ISA 700, but most frequently use the two sentences: „For these financial reports, the Company management takes the responsibility. Our responsibility is to express opinion on the financial reports, based on the conducted auditing. "

c) Incorrectly stipulated auditing standards: A significant number of audit reports stipulate that „The auditing was conducted in accordance with the Auditing standards of Federation B\&H and those are in accordance with the International standards on auditing.“ The Auditing standards of Federation B\&H were put out of effect by passing the Law on accounting and auditing 2005, which regulates ISA, legal usage. Besides, the fact is that the Auditing standards of Federation B\&H used to be in accordance with ISA until 2005. Since then, ISA has been significantly changed.

d) Incomplete description of the audit process: According to ISA 700 an audit should be described as it follows: "An audit involves performing procedures to obtain audit evidence about the amounts and disclosures in the financial statements. The procedures selected depend on the auditor's judgment, including the assessment of the risks of material misstatement of the financial statements, whether due to fraud or error. In making those risk assessments, the auditor considers internal control relevant to the entity's preparation and fair presentation of the financial statements in order to design audit procedures that are appropriate in the circumstances, but not for the purpose of expressing an opinion on the effectiveness of the entity's internal control. An audit also includes evaluating the appropriateness of accounting policies used and the reasonableness of accounting estimates made by management, as well as evaluating the overall presentation of the financial statements. We believe that the audit evidence we have obtained is sufficient and appropriate to provide a basis for our audit opinion.". However, most of the audit firms use an incomplete description as follows: "An audit involves performing procedures to obtain audit evidence about the amounts and disclosures in the financial statements. An audit also includes evaluating the appropriateness of accounting policies used and the reasonableness of accounting estimates made by management, as well as evaluating the overall presentation of the financial statements. We believe that the audit evidence we have obtained is sufficient and appropriate to provide a basis for our audit opinion."

\subsection{ERRORS OF SUBSTANCE NATURE}

Analyzing the gathered audit reports it was established that there is a number of deviations comparing to the standards ISA 700 and 701 with aspect of the substance itself. Those deviations are related to the matter as it follows:

a) Auditor inserts his own remarks into "Notes to the Financial Statements": Obviously, a number of auditors do not understand purpose and substance of Notes attached to financial reports. Frequently, auditors describe and insert spotted irregularities into Notes attached to financial reports. Attached notes pose a part of the mandatory set of financial reports and they are supposed to be the statement given by managements, not the statement given by an auditor. An auditor is only supposed to enclose all the financial report 
components together with his own audit report as well as the Notes. An auditor is not supposed to make any changes to the text that has been presented by the management. If an auditor does any corrections to the Notes it means that he presents his opinion about his own statements, not about management statements.

b) Misunderstanding of audit scope limitations: In a number of audit reports it is stated that „the previous year audit did another auditor"or „the auditor was not present to the process of inventory“, and a positive audit evaluation is stated. Consequently, potential limitations of the audit scope are unnecessary to state, and the auditor did not have scope limitations since he was in position to express his opinion.

c) Missing quantitative description of financial consequences caused by spotted irregularities: In some of the analyzed audit reports the auditor expresses his opinion with a reservation, because of irregularities in some part of a balance sheet, but does not give any quantitative description of its influence on the financial reports. According to ISA 701 "Whenever the auditor expresses an opinion that is other than unqualified, a clear description of all the substantive reasons should be included in the report and, unless impracticable, a quantification of the possible effect(s) on the financial statements. Ordinarily, this information would be set out in a separate paragraph preceding the opinion or disclaimer of opinion on the financial statements and may include a reference to a more extensive discussion, if any, in a note to the financial statements. ${ }^{3}$

d) Emphasizing the facts that are not to be emphasized: According to ISA 701 "The auditor should modify the auditor's report by adding a paragraph to "highlight a material matter regarding a going concern problem.”“4 Furthermore:”The auditor should consider modifying the auditor's report by adding a paragraph if there is a significant uncertainty (other than a going concern problem), the resolution of which is dependent upon future events and which may affect the financial statements. An uncertainty is a matter whose outcome depends on future actions or events not under the direct control of the entity but that may affect the financial statements." ${ }^{5}$ However, in some of the analyzed audit reports, it is obvious that an auditor emphasizes the facts that can be related neither to any concern nor to uncertainty.

There are some cases of emphasizing the facts that a company has not brought its documents into accord with The Law on Public Enterprises in Federation of Bosnia and Herzegovina, or the internal control system is inadequate.

e) Incorrect qualification of business continuation principles: According to ISA 701, part 6. "The auditor should modify the auditor's report by adding a paragraph to "highlight a material matter regarding a going concern problem." However, the analysis proves that the doubting any concern is handled as an issue that influences auditor opinion and consequently the auditor restrains from expressing his opinion.

The table that follows is a review of the identified deviations:

\footnotetext{
${ }^{3}$ International standard on auditing 701, \&15

${ }^{4}$ Ibidem, \& 6.

${ }^{5}$ Ibidem, \& 7.
} 
Table 1: Type of deviations classification

\begin{tabular}{|l|r|r|}
\hline Reports with no deviations & 5 & $10,42 \%$ \\
\hline \multicolumn{1}{|c|}{ TYPE OF DEVIATION } & 43 & $89,58 \%$ \\
\hline TOTAL & $\mathbf{4 8}$ & $\mathbf{1 0 0 , 0 0 \%}$ \\
\hline \multicolumn{1}{|c|}{$\begin{array}{c}\text { Number } \\
\text { of } \\
\text { deviations }\end{array}$} & Structure \\
\hline Incomplete or incorrectly defined the audit focus & 32 & $15,46 \%$ \\
\hline $\begin{array}{l}\text { Incomplete or incorrectly defined the management responsibilities for } \\
\text { Financial Reports }\end{array}$ & 36 & $17,39 \%$ \\
\hline Incorrectly stated audit standards & 18 & $8,70 \%$ \\
\hline Incomplete description of audit process & 38 & $18,36 \%$ \\
\hline Auditor inserts his own remarks into Remarks to the financial report & 27 & $13,04 \%$ \\
\hline Misunderstanding of audit scope limitations & 17 & $8,21 \%$ \\
\hline $\begin{array}{l}\text { Missing quantitative description of financial consequences caused by } \\
\text { spotted irregularities }\end{array}$ & 15 & $7,25 \%$ \\
\hline Emphasizing the facts that are not to be emphasized & 21 & $10,14 \%$ \\
\hline Incorrect qualification of going concern problem & 3 & $1,45 \%$ \\
\hline TOTAL NUMBER OF DEVIATIONS & $\mathbf{2 0 7}$ & $\mathbf{1 0 0 , 0 0 \%}$ \\
\hline
\end{tabular}

\section{LEGISLATURE IN BOSNIA AND HERZEGOVINA AS THE CAUSE FOR DEVIANT AUDIT REPORTS}

Legislature in B\&H from 1998 to 2004 was significantly harmonized with ISA. The laws on accounting and audit on Entity level were passed in 2005. The principal characteristic of those laws is their incompatibility with the state law decrees and consequently their own mutual incompatibility. Besides, the Law on accounting and audit in Federation of B\&H passed in 2005 poorly refers to the field of audit. Despite the fact that audit was a legal obligation for large turnover legal entities, it occurred that the legislator failed to define legal sanctions related to the legal obligation. There are efforts to overcome this shortage by passing some new Laws on accounting and audit on the Entity level. Until now in Bosnia and Herzegovina has not been published the translation of ISA and consequently auditors find it difficult to apply it. They are even excused from applying ISA since ISA has not been translated and officially published. The translation of the standards is supposed to be assigned to the Committee for accounting and audit as the legal obligation. In banking and insurance sector in FB\&H there are regulations that put an auditor in a position which makes him deviate from ISA. The Banking agency requires an auditor to provide additional reports. The additional requirements defined by the agency are listed in the Decree on minimal programme scope, form and content frame and the report on economy-financial audit of banking ${ }^{6}$ which was issued by the Banking Agency of Federation of B\&H. Accounting reform based on the unified Law on accounting and audit on the state $\mathrm{B} \& \mathrm{H}$ has not produced positive results in the audit field. Before the Law was passed on the state level auditors had had the Audit standards of FB\&H issued by the Federal bureau for accounting and audit at disposal to use, but nowadays the standards do not exist anymore and ISA has not been translated. From the

\footnotetext{
${ }^{6}$ Official Gazette FBiH , 3/03
} 
previously offered analysis we can conclude that the B\&H legislature considerably puts auditors in the position to deviate from ISA.

\section{EDUCATION OF AUDITORS IN B\&H AND ITS INFLUENCE ON QUALITY OF AUDIT REPORTS}

The analysis of quality of education of auditors was conducted in two ways:

$\square$ The analysis of education required for accountants and auditors to qualify for the profession

$\square$ The analysis of continuous accountants and auditors education

In accordance with the Law on accounting and audit on B\&H state level it has been formed the Commission for accounting and audit. The commission is authorized for translation and publishing standards, and in certain circumstances it can give directives and explanations for the directives. The commission is in charge of conducting the uniform education program for qualification to accounting business), coordinating with professional bodies and educational services it publishes the required instructions which are necessary for the appropriate and uniform application of the program in the whole territory of B\&H. In practice, getting a professional title in $\mathrm{B} \& \mathrm{H}$ is rather undefined. The comity for accounting and audit is only formally in charge of the matter, in a way that it transferred the mission to the entity accountant and auditor associations. The analysis of education required to qualify for an accounting or auditing vocation was conducted through analysis of the required answers to the quizzes given to the professional auditor nominees in the period of November 2007, May 2008, May 2009, and November 2009 downloaded from the web page owned by the Accountants, auditors and financial branch association of FB\&H (SRRF B\&H). The analysis of the required answers for the time periods proved that there are certain deviations if we compare them to the International standards on auditing (ISA). The analysis proved that the auditor candidate testing process itself is faulty because in many cases wrong answers are rated correct even though they are not in accordance with auditing standards. The goal that we defined when started the analysis of the continuous education was to establish if auditors get appropriate continues education, in other words get the answer if the education content declared by the official entities in charge of conducting the education may be the cause of subjective weaknesses of auditors which show up though the creating deviant audit reports. Until now, four consulting firms from Federation of Bosnia and Herzegovina, authorized by the experts in the field association, have taken part in conducting the education program. The research and the analysis was conducted by gathering information regarding the topic contents and lectures given through certain forms of education in 2009 and also by classifying according to areas: Accounting standards, annual and semi-annual balances, tax issues, budget accounting, finances, audit and other topics. Analyzing the structure of seminars, which have the status of confirmed and continuous education in 2009 and in the first four months in 2010 it was confirmed that all in all 168 seminars which were organized by 4 consulting firms (142 seminars in 2009 and 26 seminars in the first 4 months in 2010) discussed none of audit topics. Analyzing the special field topics of education it was established the structure of education as it follows: 
Table 2: Education topics structure

\begin{tabular}{|l|r|r|}
\hline TYPE & Seminars & Structure \\
\hline Budget & 6 & $4,23 \%$ \\
\hline Finances & 2 & $1,41 \%$ \\
\hline IAS and IFRS & 25 & $17,61 \%$ \\
\hline Balance & 17 & $11,97 \%$ \\
\hline Other & 13 & $9,15 \%$ \\
\hline Tax & 79 & $55,63 \%$ \\
\hline TOTAL & $\mathbf{1 4 2}$ & $\mathbf{1 0 0 , 0 0 \%}$ \\
\hline
\end{tabular}

The table clearly shows that the majority of the topics are related to the tax issues (55\%) while audit topics were not discussed at all. Three of the education sessions organizers organized international symposiums. Those symposiums treated the topics as it follows.

Table 3.: Audit field topics - International symposium 2009 listed by performers

\begin{tabular}{|c|c|c|}
\hline SYMPOSIUM & & TOPIC \\
\hline \multirow{5}{*}{ REVICON } & 1 & Audit and analysis of financial reports \\
\hline & 2 & Audit of efficiency and measuring success in public services \\
\hline & 3 & Most frequent deviations and remarks of audit institutions of B\&H \\
\hline & 4 & Tendencies in public services audit \\
\hline & 5 & $\begin{array}{l}\text { Most common irregularities and remarks in audit findings in FB\&H } \\
\text { institutions }\end{array}$ \\
\hline \multirow{4}{*}{ FEB } & 6 & Audit of business operating in unstable circumstances \\
\hline & 7 & Accounting and audit of bankruptcy \\
\hline & 8 & International framework of internal auditor professional performance \\
\hline & 9 & Current changes in international audit standards \\
\hline \multirow{5}{*}{ FIRCON } & 10 & Auditor performance quality control- theory and practice \\
\hline & 11 & INTOSAI audit standards and application in public services audit \\
\hline & 12 & Public supervision committee and auditor performance quality control \\
\hline & 13 & Financial report audit quality control according to ISA 220 \\
\hline & 14 & ISA 240 - framework for defining of the auditor role in uncovering of fraud \\
\hline
\end{tabular}

From the topic titles it is obvious that half of the topics are related to audit of public services and those only 7 topics are related to the external commercial audit field. It is important to mention that the seminar presentations for each topic lasted for up to 15 minutes. On that base we can make a conclusion that less than two school periods were spent on the discussion related to external commercial audit. Because of the law definitions currently in effect auditors are not in position to influence directly on the education structure. Despite the fact that the Accounting and auditing commission is authorized for education and certification, it authorized the Accounting, audit and financial field experts of FB\&H association to perform instead. However, auditors have no influence o on the association because of the reasons as it follows:

$\square$ Auditors are not present to the Association meetings since the meetings are not held publicly and transparently. Not all the members are invited to the meetings but only the 
representatives of the associations that established the Association and who are controlled by the consulting firms "Revicon", "FEB" and "Fircon."

$\square$ The Association bylaw has never been published and consequently the members, especially auditors do not know their rights and obligations.

Regarding the education auditors are the same way as the other members of the Association put in the same position despite the fact that other members are far less educated (the majority of other members have only a high school diploma). The research clearly indicated that the auditors in B\&H do not get proper education while attending the course to get the title, and also the continuous audit field education almost does not exist.

\section{TOTAL NUMBER OF PUBLISHED AUDITS AND ITS INFLUENCE ON THE AUDIT REPORTS QUALITY}

One of the research goals was to quantify the total number of audits in relation to the total number of legal entities in FB\&H, find the answer to the question if $\mathrm{B} \& \mathrm{H}$ auditors have a chance to get appropriate practice and if the insufficiently developed audit practice could be the cause of deviations in audit reports comparing to ISA. The quantification of the number of audits carried out comparing to the total number of legal entities in FB\&H in 2009 was carried out on the sample that consists of: processing industries, (sample-57 legal entities), banks and insurance companies. It was established and confirmed that 3816 processing industry subjects turned in their financial reports for 2009 to AFIP in appropriate legal forms. The analysis was conducted on the sample of 57 legal entities which turned in their reports to the Securities commission for the time period of the year 2009. The analysis established that 27 legal entities did audit which presents $47 \%$ of the total number of the analyzed legal entities. It was established that 4 of the legal entities had the audit in progress which presents $7 \%$ of the total number. The other 26 legal entities which present $46 \%$ of the total number had not audit done yet. It is necessary to emphasize that most of the legal entities in processing industry in FB\&H are registered as companies with limited liability. Consequently, they are not legally obliged to turn in to the Commission neither financial nor audit reports. It is obvious that those companies with limited liability show poor transparency

in their financial reporting. The research establishes the fact that banks and insurance companies do financial report audits, especially because audit liability is imposed by the special regulations issued by supervision agencies. However, in $90 \%$ of the cases, banks and insurance companies look for internationally licensed audit firm's services, and consequently most of the FB\&H audit firms have no opportunity to audit in this business field. The analysis also proved that $\mathrm{B} \& \mathrm{H}$ auditors have no opportunity to get the proper practice since very few audits are done in FB\&H. Audit is conducted in share holding companies as well as the companies that are required to do so according to some other requirements. Those companies are subjected to be supervised by some special standards (banks, insurance companies, investment fund organizations, public enterprises). However, most of companies with limited liability evade audits (even big companies) taking advantage of the previous Law on accounting and auditing (2005) shortages. Insufficiently developed audit practice with no doubt is a significant cause for erroneous audit reports. 


\section{QUALITY CONTROL OF AUDIT, PUBIC SUPERVISION OF AUDITORS IN B\&H AND THE REFLECTION IN THE AUDIT REPORT QUALITY}

The analysis confirmed that the number and the structure of the employees in audit firms, in any case, poses a key factor for the quality control policies, demanded by the international standards, to be put in practice. The research on the number and the structure of employees in audit firms in B\&H was conducted on sample basis, through the questionnaire which included 32 audit firms in its scope. The questionnaire required information as it follows: total number of employed certified auditors, official book of regulations at disposal.

It is necessary to emphasize that the audit firms, the branch offices of big international audit firms were excluded from the analysis of application of the audit quality control principle. Anyway, these audit firms are obliged to conduct the quality policy established by their mother organizations.

The questioner analysis results are as it follows:

Table 4: Number and structure of employees in audit firms in FB\&H

\begin{tabular}{|l|c|c|c|c|c|c|c|c|}
\hline & $\mathbf{1}-\mathbf{2}$ & $\mathbf{3}-\mathbf{5}$ & $\mathbf{6}-\mathbf{1 0}$ & $\mathbf{1 1}-\mathbf{1 5}$ & $\begin{array}{c}\text { over } \\
\mathbf{1 5}\end{array}$ & YES & NO & TOTAL \\
\hline $\begin{array}{l}\text { NUMBER OF } \\
\text { EMPLOYEES }\end{array}$ & $\mathbf{1 8}$ & $\mathbf{9}$ & $\mathbf{2}$ & $\mathbf{2}$ & $\mathbf{1}$ & & & $\mathbf{3 2}$ \\
\hline $\begin{array}{l}\text { NUMBER OF CERTIFIED } \\
\text { AUDITORS }\end{array}$ & $\mathbf{3 1}$ & $\mathbf{1}$ & & & & & & $\mathbf{3 2}$ \\
\hline $\begin{array}{l}\text { BOOK OF } \\
\text { REGULATIONS AT } \\
\text { DISPOSAL }\end{array}$ & & & & & & $\mathbf{2}$ & $\mathbf{3 0}$ & $\mathbf{3 2}$ \\
\hline
\end{tabular}

The analysis indicates that more than a half of the total number of audit firms has one or two employees, almost all of the firms have one or two certified auditors, and only two firms have a quality control rule book. Having in mind the circumstances, it is obvious that at least a part of the standard quality control elements is not possible to be applied in practice in audit firms in FB\&H, especially the components as it follows: task distribution, authorization, advising and observation.

Since the Law on accounting and audit in FB\&H (2005) was passed, the role of public supervision is practically held by the Ministry of finance B\&H. However, the research proves that the Ministry has not published a single report on public supervision conducted. None of the audit firms of an auditor has been decertified (except the cases of reregistration). None of the audit firms or auditors was officially denounced.

These arguments prove that the Ministry has not put in operational practice public supervision role. Besides, it has not taken any measures in this field. That is, by all means, a significant cause for poor quality of the published audits reports.

\section{CONCLUSION}

The analysis of the gathered audit reports proved that there is a number of deviations if Compared to ISA 700 and 701, from the formal text content aspect as well as the essence aspect, taking in consideration both commercial auditors and government auditors in B\&H. 
Analyzing the Legislative regulations in the audit field in B\&H and its influence on audit report quality, it has been proved that in a part of the legislature in $\mathrm{B} \& \mathrm{H}$ there are some regulations that have negative influence on audit quality. The analysis of education required to qualify and acquire the certification in accounting and audit profession, and also the analysis of continuous education of accountants and auditors, conducted by the experts in the field association, indicated that the auditors in FB\&H have no opportunity to get the proper education to ensure their performance in accordance with ISA. The analysis of the total number of audits and its influence on the audit reports quality indicated that most of B\&H auditors have no opportunity to get enough practice, and insufficiently developed audit practice presents a significant cause for creating erroneous audit reports. The analysis of audit quality control and public supervision control in FB\&H it was proved that the quality control rendered by audit firms in most cases is not credible because of the small number of employees in audit firms, and the external quality control and public supervision in than last 5 years existed only formally. They have been put in practice by the ministry in charge. In order to overcome the current situation in audit field it is necessary to adapt the legal regulations in the audit field to the real requirements of the audit business, and also publish the translation of ISA to the local languages as soon as possible. The audit firms should establish the Audit Chamber and eliminate the problem of the audit field disunity and the problem of not making difference between auditors and accountants and sometimes between auditors and high school educated accountant technicians, regarding the education. It is also necessary to adapt the Education program for auditors according to the real requirements on the market that the auditors encounter, in a way that the education topics the related to the audit issues take more places in the education program initiated by the experts in field associations in charge of conducting the seminars and education. In order to improve the audit quality control

it is essential to establish an appropriate regulatory body to control the audit associations performance and also control the certified auditors performance. It is also supposed to establish public supervision over the regulatory body in charge of the quality control, over the audit organizations and certified auditors, in order to contribute to the harmonization of operating the mentioned business subject in business.

\section{REFERENCES}

Andrić,M., Revizija računovodstvenih iskaza, Ekonomski fakultet Subotica, 2002.

Andrić,M., Revizija - teorija i praksa, Ekonomski fakultet Subotica 2009.

(2009), Handbook of International Standards on Auditing and Quality Control, 2009.

Jahić, M. Finansijsko računovodstvo: MSFI - MRS - PDV. Sarajevo: Udruženje revizora FBiH, 2008.

(2009.) Međunarodni revizijski standardi, Hrvatska revizorska Komora, Zagreb,

Meigs W. B. - Whittington O. R. -. Pany K. J - Meigs R. F., Principles of Auditing, Homewood, Illinois, Irwin, 1988.

Messier, W. F. Revizija: priručnik za revizore i studente s rješenjima zadataka. Zagreb: Faber\&Zgombić Plus, 2000.

Soltani B. Revizija: Međunarodni pristup, Mate d.o.o., Zagreb 2009.

Šapina H. „Revizijski rizik kod zaliha podložnih tehnološkim gubicima“, doktorski rad, Ekonomski fakultet Sarajevo, 2009.

(2003) Zakon o privrednim društvima Federacije BiH: - «Službene novine Federacije BiH», broj 23/99, 45/00, 2/02, 29/03.

(2005) Zakon o reviziji u FBiH, «Službene novine Federacije BiH 2/05.

(2009) Zakon o računovodstvu i reviziji u FBiH: - «Službene novine Federacije BiH», broj 83/09. 


\title{
RAZLOZI REVIZORSKIH GREŠAKA U OBJAVLJENIM REVIZORSKIM IZVJEŠTAJIMA U BOSNI I HERCEGOVINI
}

\begin{abstract}
SAŽETAK
Autori su realizirali istraživanje u okviru kojeg su identificirane greške u objavljenim revizorskim izvještajima bosanskohercegovačkih nezavisnih revizora, te analizirani uzroci uočenih grešaka. Analizom prikupljenih revizorskih izvještaja utvrđeno je da postoje brojne devijacije u odnosu na zahtjeve Međunarodnih revizijskih standarda 700 i 701, kako sa aspekta formalnog sadržaja teksta izvještaja, tako i sa suštinskog aspekta. Istraživanjem je utvrđeno da su uzroci identificiranih grešaka: neadekvatna zakonska regulativa u BiH, neodgovarajuća kontinuirana edukacija revizora, nedovoljna razvijena revizorska praksa, nedostatak interne kontrole kvaliteta u većini revizorskih firmi te nedostatak javnog nadzora na nivou države. Novi Zakon o računovodstvu $i$ reviziji otvara prostor za određena poboljšanja, a naročito kroz osnivanje Revizorske komore i Odbora za javni nadzor.
\end{abstract}

Ključne riječi: Međunarodni revizijski standardi, revizijski izvještaji, greške revizora 